\title{
Nutrients in the Upper Mississippi River: Scientific Information to Support Management Decisions
}

\section{The Upper Mississippi River- Values and Vulnerability}

The Upper Mississippi River (UMR) flows south about 1,300 miles from its headwaters in Minnesota to its confluence with the Ohio River at Cairo, Illinois. The river gains volume along its path as it drains nearly 190,000 square miles $\left(490,000 \mathrm{~km}^{2}\right)$ of land, extending over parts of South Dakota, Minnesota, Wisconsin, Iowa, Illinois, and Missouri (fig. 1).

The UMR is valued as a multiple-use resource where commercial navigation, water supply, and recreational demands coexist with valued natural resources. Some 70-80 million tons of commodities are transported on the river annually. More than 30 million residents rely on river water for uses such as public and industrial supplies and power plant cooling. The river hosts about 12 million recreational visitors annually. When the public has been asked to identify priorities for the river, however, environmental uses were considered more important (Carlson, 1999). The river is home to a wide variety of wildlife, fish, and aquatic invertebrates. Added to these yearround residents are the many bird species that migrate through the corridor or stop seasonally to breed or overwinter (fig. 2). The fact that three major National Wildlife Refuge

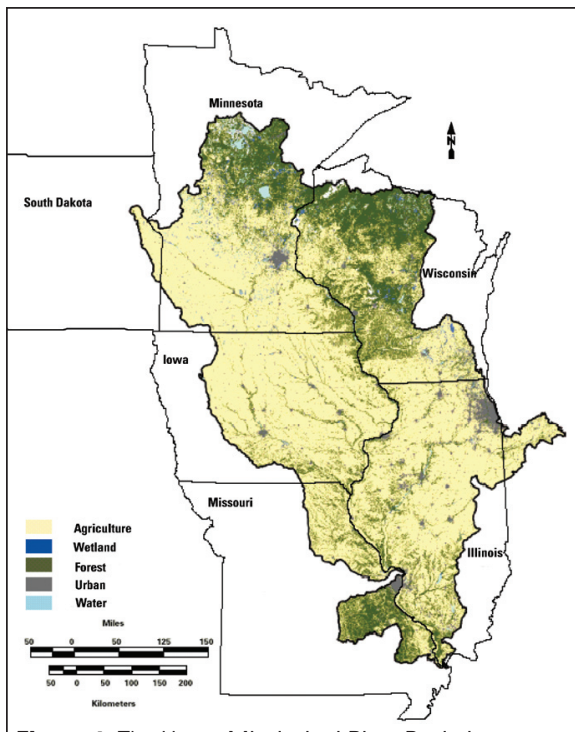

Figure 1. The Upper Mississippi River Basin is dominated by agricultural land with some forest and major urban areas. complexes and several National Park units have been established along the corridor of the UMR reflects the river's importance to the natural resources of the Nation.

Water quality of the UMR is critical to the ecological health of the system and is intricately linked to the basin's vast drainage, most of which is used for agriculture (fig. 1). Nitrogen and phosphorus are abundant in the drainage basin because of the widespread use of commercial and animal-manure fertilizers. In fact, the quantity of nitrogen and phosphorous lost from the land to the stream ("yields") in the Upper Mississippi River Basin (UMRB) is higher than in any other portion of the Mississippi River Basin (fig. 3).

Nitrogen and phosphorus are essential nutrients but in excess can be detrimental to aquatic health. Specifically, elevated nutrients accelerate photosynthesis, which produces nuisance growth or "blooms" of algal or other plant biomass that can be problematic. First, they are unsightly and can impede recreational uses and aesthetics. Second, excessive plant growth can damage habitats for other biota and impair the general ecological health of the aquatic ecosystem. Finally, and probably most extensive, is the effect of excessive growth of algae and other plants on the depletion of oxygen. When these plants die, their rapid decomposition can consume oxygen at a high rate and can result in low concentrations of dissolved oxygen (hypoxia). Low dissolved oxygen can be highly stressful or even fatal to fish and other biota in the river.

Excessive nutrients, along with sediments and pathogenic microorganisms, are among the leading causes of impaired streams in the UMRB. Impaired streams cannot fully support aquatic biological communities or other designated uses set by states and tribes. A Federal regulatory process establishes Total Maximum Daily Loads (TMDLs), a legal definition of the total quantity (or load) of a pollutant that a stream can carry and still meet designated uses and fishable or swimmable quality levels (U.S. Environmental Protection Agency, 2003; http://oaspub.epa.gov/waters hational_rept.control).

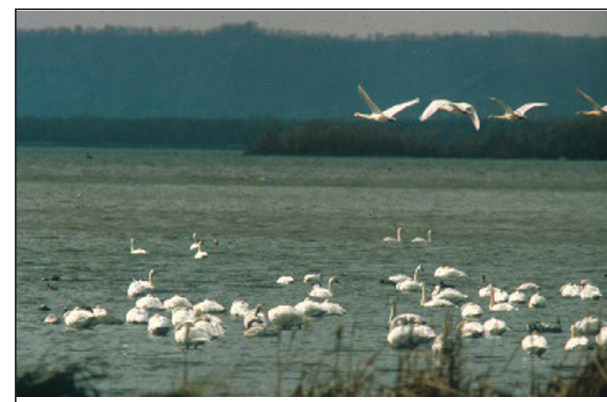

Figure 2. The Upper Mississippi River supports a high diversity of wildlife and is a major migration corridor for birds.

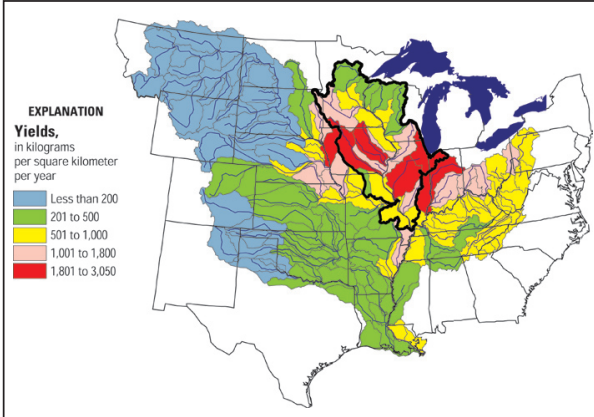

Figure 3. Average annual nitrogen yields of streams for 1980-96 (modified from Goolsby and others, 1999).

\section{Science in the Upper Mississippi River: Role of the U.S. Geological Survey}

The U.S. Geological Survey (USGS) leads the Nation in long-term data collection and research of natural water systems throughout the Nation. As a nonregulatory Federal agency, the USGS provides objective science needed to resolve difficult or controversial resource allocation issues. Also, it has a dedicated focus on the UMRB because of the river's local, regional, and national ecological and economic importance. Specifically, the USGS

- maintains an established network of hydrologic and water-quality monitoring sites on the Mississippi River and its tributaries;

- conducts a multitude of individual studies assessing interactions among physical, chemical, and biological processes; and

- provides analysis and modeling of the linkages between the watershed, the river, and aquatic biota.

Such information is essential to the preservation of the health and vitality of the aquatic ecosystems of the UMRB. 
Adequate monitoring on multiple scales and interdisciplinary research is required to develop knowledge of water issues and trends, specifically to understand nutrient transport and the potential effects of nutrients on the ecosystem and on human uses of the water. Information derived through monitoring and research activities provides an improved scientific basis for effective management policies and strategies to reduce or eliminate water-quality problems within the UMRB. Also, the information helps with decisions involving competing demands for navigation, safe drinking water, aquatic ecosystem health, irrigation, wetland protection, and recreation. Specific applications of the science to local and regional decision-making and policy formation are many and far-reaching, including

- implementing and evaluating management actions such as agricultural and urban management practices, forest and riparian buffers, wetland restoration, and water diversions to reduce nutrients in the UMR main stem;

- assisting states, tribes, and other regulatory parties involved in the development of TMDLs; and

- providing an understanding of critical factors-i.e., basin characteristics, landuse patterns, water management, and climate - that affect nutrient sources, transport, and loads needed to address effects on downstream water users such as fisheries in the Gulf of Mexico.

\section{Long-Term Monitoring Programs}

The UMRB has benefited from several distinct long-term monitoring programs that measure streamflow, water quality, and biological responses. Long-term monitoring provides a quantitative approach to answer the question "Are stream conditions getting better or worse?" Water resources are constantly changing, seasonally and annually, because of both natural factors such as climate change and human factors such as urbanization. Consistent and systematic monitoring over the long term is critical to evaluate benefits of implemented management plans, controls, and strategies. Long-term monitoring programs provide a body of data on hydrologic and biologic conditions and in-place field sampling capabilities that allow focused modeling and research studies (discussed later in this document) to more cost effectively explain regional and national impacts.

The USGS manages four national or regional long-term monitoring programs that provide data and information about the UMR (Table 1). Each program is designed to meet specific needs and objectives and includes different parameters, frequencies of collection, and sites. Defined and consistent sampling and analysis methods are used in each program so the monitoring data can identify trends over large regions and long periods of time.

Within the UMRB, the USGS organizes and integrates available information over time

\section{Hypoxia in the Gulf of Mexico}

Chronic loading of nutrient-

laden water from the Mississippi River over the last 30 years has produced excess algal growth and resulted in a large zone of hypoxia in the waters of the Gulf of Mexico near the mouth of the Mississippi River (fig. 4; Rabalais and others, 1999; Goolsby and Battaglin, 2000). Nitrogen tends to be the nutrient limiting algal growth in marine ecosystems and the size and frequency of the zone of hypoxia is correlated to the quantity of nitrogen loaded into the Gulf of Mexico (Rabalais and others, 1999). Recent studies (Goolsby and others, 1999; Alexander and others, 2000) indicate that nearly 90 percent of nitrogen input to the Gulf is from nonpoint-source runoff.
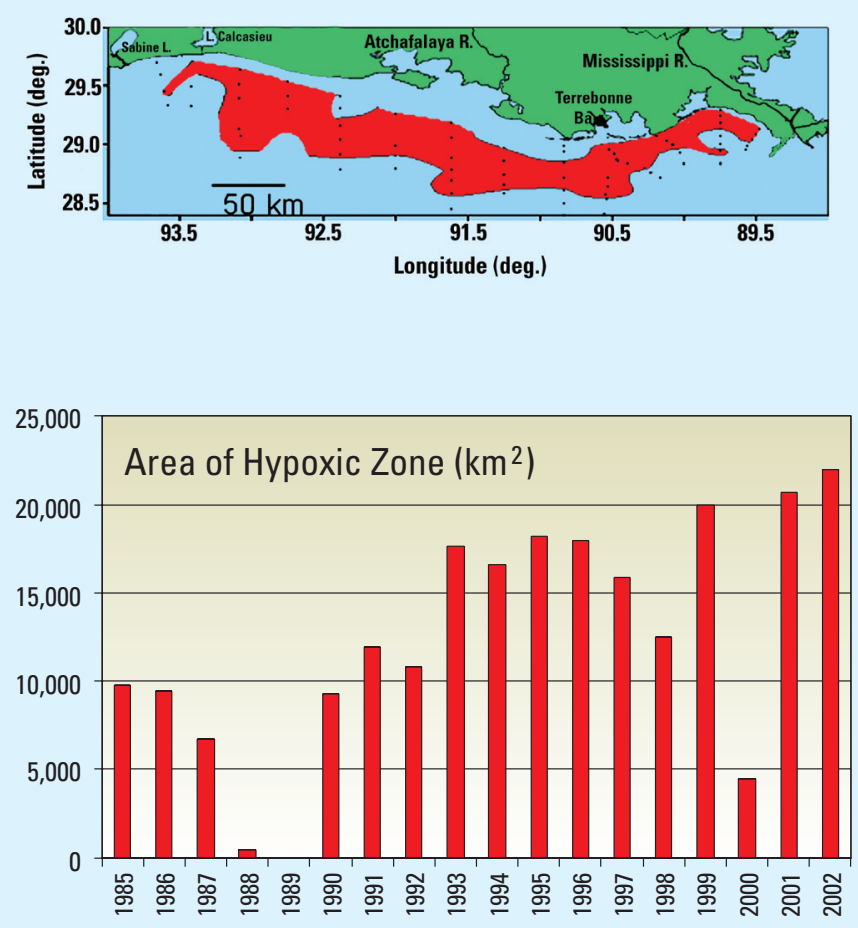

Figure 4. Hypoxia zone in the Gulf of Mexico near the mouth of the Mississippi River was roughly the size of Massachusetts in 2002. and across physical, chemical, and biological aspects of the river system to develop the most comprehensive understanding of the UMR.

This understanding includes all components of the hydrologic cycle, interactions among the components (such as streamflow and groundwater), and responses of the aquatic life to water quality and streamflow. Even with the resources of these long-term programs, there are unmeasured and unexplained processes that contribute to the variability observed in the UMRB. Unmet needs for research and longterm monitoring can be defined based on gaps in our current understanding from the existing programs.

About 190 streamflow gaging stations in the UMRB (U.S. Geological Survey, 1999b) provide continuous (24 hours a day) and, frequently, "real-time" (updated at intervals of 4 hours or less) streamflow information (http://water.usgs.gov/nsip). These gages are supported either through the USGS National Streamgaging Network (NSN: some sites in the UMR were established in the late 1800s, but most were established in the 1930s) or the National Streamflow Information Program (NSIP, begun in 1999). Sites in the NSN Program are cost-shared with local and state cooperators; NSIP sites commonly are completely supported with Federal funds. The combination of these two programs provides streamflow information critical for interstate treaties, basin and regional water assessments, planning studies, flood forecasting, and waterquality and biological assessments (Hirsch and Norris, 2001).

A variety of water-quality and selected biological information has been collected in the UMR by the National Stream Quality Accounting Network (NASQAN, 1974present). Monthly to semi-annual sampling was conducted at about 50 sites during the period 1974-95 to measure long-term changes in water quality at the terminus of the country's major watersheds and at most major subbasins. NASQAN was refocused in 1996 to increase coverage of additional chemicals of concern as well as to improve coverage of high flows for improved reliability of annual loads that can be significantly influenced by relatively few days of high flow. From 1996 to present, NASQAN continues to sample three locations in the main stem UMR (Clinton, Iowa; Grafton, Missouri; and the UMR terminus, Thebes, Missouri) from 9 to 15 times per year (figs. 5 and 6). For additional information, access http: /water.usgs.gov/nasqan.

In contrast to NASQAN, four study areas in the UMRB have been examined in much more detail by the National Water-Quality Assessment (NAWQA) Program: Eastern Iowa Basins, Upper Mississippi River Basin (smaller than the UMRB defined in this fact sheet), Upper Illinois River Basin, and the 


\section{Scientific Approach to Providing Information For Managing Natural Resources in the Upper Mississippi River Basin}

Included in U.S. Geological Survey (USGS) investigations are long-term monitoring programs, regional modeling studies for estimating and predicting water and nutrient transport in the Upper Mississippi River, and research that focuses on processes affecting transformations and transport of nitrogen and phosphorus in streams and river systems. Numerous smaller-scale studies of water resources are conducted throughout the basin as part of cooperatively funded efforts among USGS and other agencies to develop practical solutions to local water problems. All of these components work together to provide information in the management decision process to resolve biological, land, and water resource use conflicts.

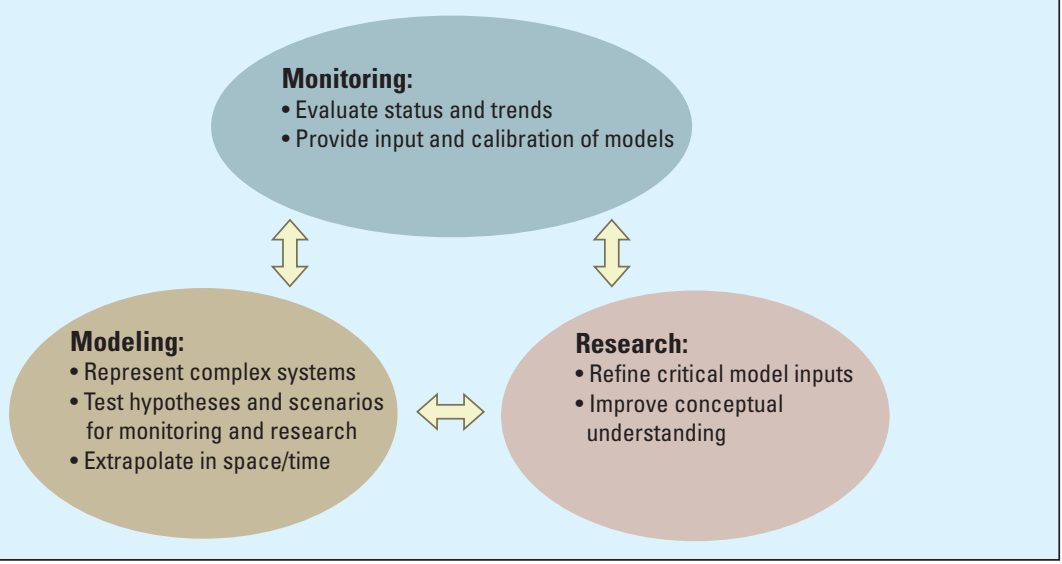

Lower Illinois River Basin (fig. 5). These areas are part of a national program of more than 50 basins studied. NAWQA was designed to describe the condition of our Nation's streams and groundwater, how those conditions change over time, and how natural features and human activities affect the quality of streams and groundwater. By combining information on water chemistry, physical characteristics, stream habitat, and aquatic life, the NAWQA Program provides science-based insights for current and emerging water issues and priorities (e.g., Sullivan, 1999; Kalkoff and others, 2001). During the next decade, these NAWQA study areas are scheduled to be revisited so that 20 years of data, supplemented with detailed process studies, can be used to assess long-term trends supported with process understanding of those trends. For additional information, access http://water.usgs.gov nawqa

Long-term monitoring data focused on major biological, physical, and chemical components of the UMR ecosystem are collected by the Long Term Resource Monitoring Program
(LTRMP; U.S. Geological Survey, 1999a). The LTRMP began collections in 1988 to provide decision makers with the information needed to maintain the UMR as a viable multiple-use large river ecosystem. Funds are provided by the U.S. Army Corps of Engineers for USGS to implement the LTRMP in cooperation with five Upper Mississippi River System states. The LTRMP's primary water quality focus, in contrast to the programs already discussed, is on limnological variables known to be significant to aquatic habitat. Limnological and a suite of biological samples are collected in 4 of the 27 navigation pools of the UMR, a reach of the Illinois River, and a portion of the open, unimpounded river to obtain reach-wide estimates for trend detection (fig. 5). Additional limnological samples are collected near several major tributaries in the UMR. The LTRMP data have been particularly useful in documenting the finer spatial distribution of nutrients in the navigation pools (low-head reservoirs) that impound the upper portion of the UMR main stem. For additional information, access http: /www.umesc.er.usgs.gov/ltrmp

\section{Modeling Nutrient Transport and Loads}

Effective strategies for managing nutrients and water-quality issues require far more information than that available from monitoring data alone. Continued development of reliable computer models improves the ability to forecast the fate and transport of nutrients for unmonitored locations over different time frames, geographic areas, and environmental settings. Models are an essential component of a cost-effective management strategy over broad regions such as the UMRB.

Table 1. Summary of U.S. Geological Survey monitoring programs on the Upper Mississippi River and tributaries.

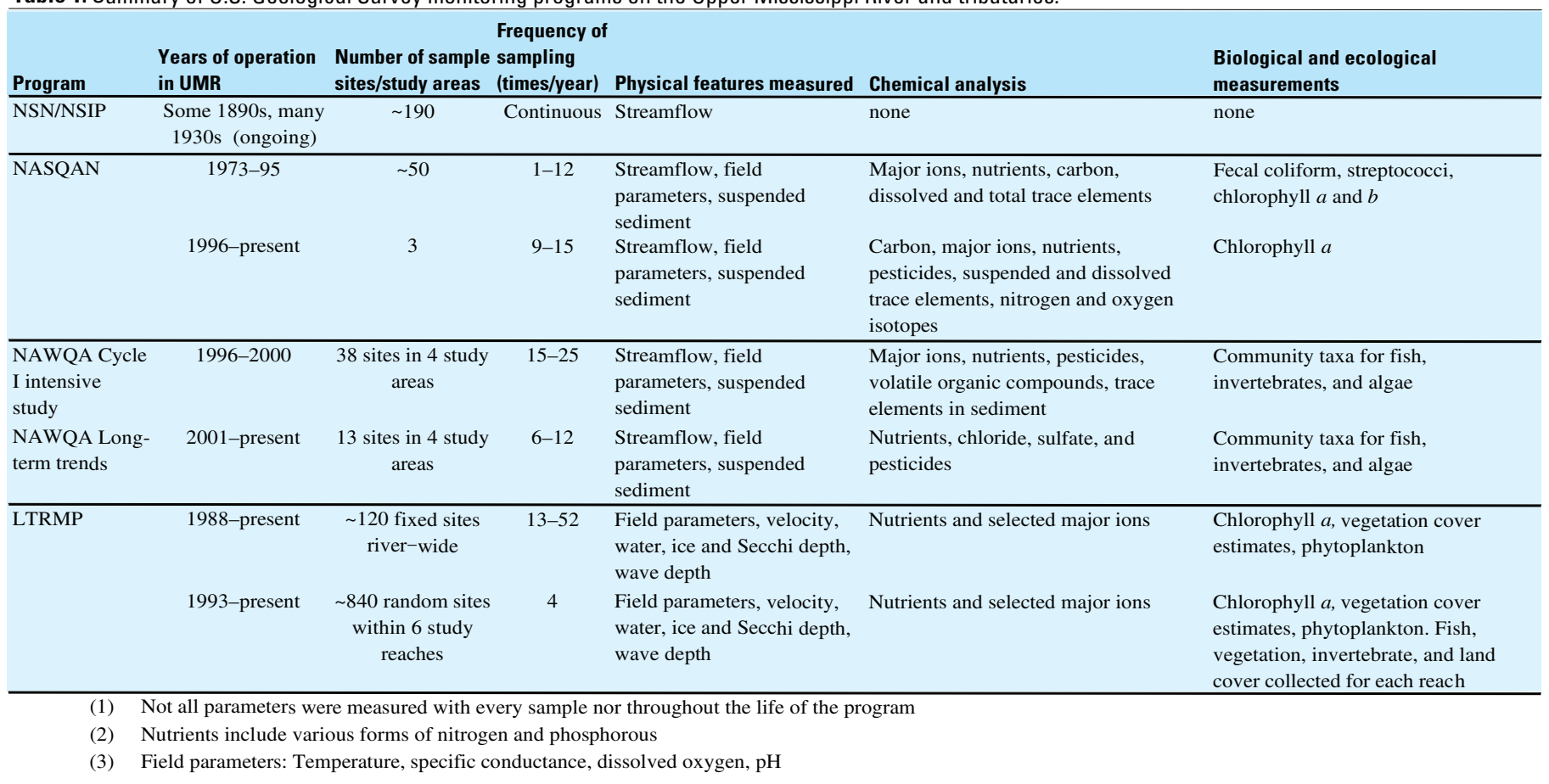




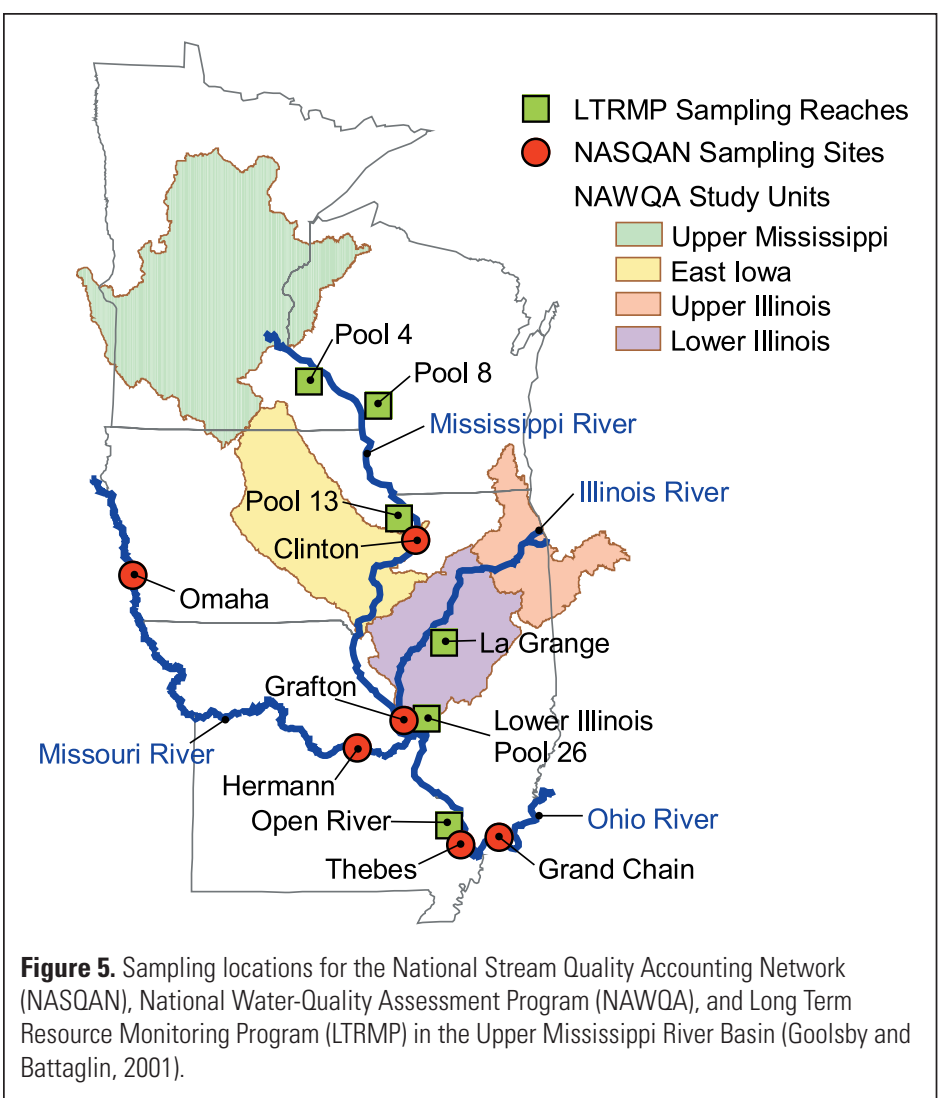

Several USGS models have been used to characterize annual and seasonal nitrogen sources and loads in the UMRB. The SPARROW model (SPAtially Referenced Regression on Watershed Attributes) is used to estimate large-scale transport of nitrogen (Alexander and others, 2000) through the integration of watershed data, including landuse and landscape features, over multiple spatial scales. Streamflow and water-quality data from the NSN, NASQAN, and NAWQA programs are used to calibrate and verify the model's reliability for representing actual conditions. The in-stream transport model (DAFLOW/BLTM) simulates stream discharge and transport of nitrate. With this model, Broshears and others (2001) simulate the movement of nitrate from the downstream boundary of the UMR to the Gulf of Mexico. Certain types of hydrologic or water-flow models focus on groundwater-derived river flow (baseflow), which accounts for most of the river flow under low runoff (nonstorm) conditions. Outputs from these models can be used to compare the importance of different water sources and losses.

\section{Studies of Processes Controlling Nutrient Movement, Fluxes, and Transformations}

Studies of processes provide information for improved understanding of nutrient sources, cycling, and transport. The information can be used to improve model development and aid in management decisions for the protection of water quality and habitat.

\section{Nitrogen removal processes}

A number of USGS studies are conducted in backwater areas and pools in the UMR to examine nitrogen removal processes such as denitrification. Denitrification is an important natural and beneficial microbial process in which nitrate is converted to a nonreactive nitrogen gas that is released to the atmosphere. Backwater areas and pools often provide optimal settings for denitrification because they contain anaerobic sediments (no oxygen present) high in carbon and dense beds of aquatic plants, but receive high amounts of nitrate mostly during flooding. Laboratory and field experiments have shown that introduction of water from the UMR main stem to backwater areas results in increased rates of sediment denitrification and nitrate uptake and removal (Richardson and others, in press; Strauss and others, in press). This work has shown that a potentially effective management option for increasing removal of nitrate is the diversion of nitrate-rich water from the main stem into backwater areas during nonflooding periods. Research on nitrogen processing in the UMR has depended on both new innovative research and high quality nutrient-loading estimates provided by the LTRMP.

The potential to manage the UMR to remove nitrogen is greater in the impounded reaches of the UMR than in lower reaches. Above St. Louis, Missouri, the UMR is managed for navigation through impoundment of 27 river reaches (pools). Impoundment of the floodplain has resulted in a high degree of connectivity between the main stem and backwaters (many of which are managed and protected under the National Wildlife Refuge System) that allows water movement throughout the floodplain. In contrast, the Lower Mississippi River is effectively disconnected from its floodplain by flood-control levies, and this disconnection prohibits nutrient-rich water from interacting with the carbon-rich floodplain ecosystems. An experimental water-level manipulation within one UMR navigation pool that mimicked preimpoundment, natural river, fluctuations by reducing water levels during late summer has shown promise for reducing nitrogen levels and improving water quality. USGS scientists showed that drying and wetting of sediments during such manipulations results in significant removal of nitrogen stored in sediments, while also increasing abundance of aquatic plants critical for fish and wildlife needs (Strauss and others, 2003).

Another study of sediment and water chemistry at wetland sites near Navigation Pool 8 (near La Crosse, Wisconsin) is to determine patterns of nitrogen uptake and cycling by floodplain wetlands, forest soils, and riverine sediments in different seasons and at different river stages. Information about this study can be accessed at http://www.umesc.usgs.gov/aquatic/ brichardson_5003475.html.

\section{Source characterization using isotopes of nitrate and organic matter}

The USGS has conducted research in the UMRB to delineate nitrogen and oxygen isotope ratios, research that can provide useful information about nutrient sources, land uses, and nitrogen recycling processes that contribute nitrogen to the river (Battaglin and others, 2001; Chang and others, 2002). The ratio of nitrogen isotopes in aquatic biota has proven useful in assessing the relative importance of plant uptake and microbial denitrification leading to nitrate removal. Significant terrestrial sources of nitrate, as well as variations in land use, are revealed in the patterns of nitrogen and oxygen isotopes of nitrate.

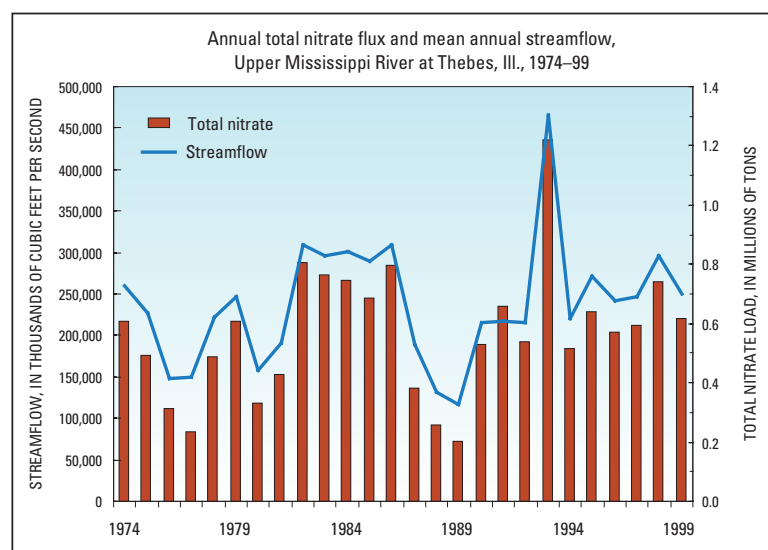

Figure 6. National Stream Quality Accounting Network monitoring since 1974 near Thebes, Illinois, defines stream flow and contaminant loads leaving the entire Upper Mississippi River watershed. The annual mean stream flow (average flow rate during a 1-year period, measured in cubic feet per second), and total nitrate load (mass of total nitrate transported downstream during the year) are highly variable from one year to another because of drought (for example, 1988-89) and floods (for example, 1993). However, total nitrate fluxes leaving the Upper Mississippi River Basin have not increased or decreased significantly over the 27-year period (Goolsby and Battaglin, 2001). 


\section{What Management Information does the SPARROW Model Provide?}

Model results (from SPAtially Referenced Regression on Watershed [SPARROW]) indicate that the sources of nitrogen delivered to the Gulf of Mexico are predominantly nonpoint sources and of the three primary types of land use (forest, agriculture, and urban), agricultural lands produce the largest yields of nitrogen and phosphorus. These model results are consistent with results from the Upper Mississippi Basin National Water-Quality Assessment study (fig. 7). In addition, modeling results show that proximity of nitrogen sources to large streams and rivers increases the amount of nitrogen transported to the Gulf (Alexander and others, 2000). This is because nitrogen is not removed as readily in the large streams and rivers by natural processes as in the smaller tributaries, and is, therefore, much more likely to reach a coastal area. As a result, some watersheds in the Mississippi River Basin contribute more nitrogen to the Gulf than others, despite similar nitrogen sources or large distances from the Gulf. This knowledge allows nitrogen-control efforts to be focused in these more highly contributing areas.

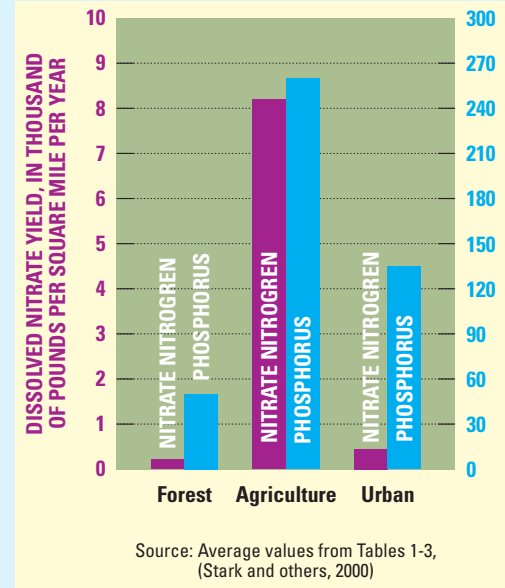

Figure 7. Nutrient yields are greatest in streams draining agricultural areas (Source: Average values from Tables 1-3 [Stark and others, 2001]).

Nitrogen and carbon isotopes, along with other chemical and hydrologic measurements, have been used to determine the relative contributions of terrestrial and aquatic particulate matter to the Mississippi River (Kendall and others, 2001). Approximately half of the nitrogen transported by the Mississippi River is in the form of organic matter (Goolsby and Battaglin, 2001). If this organic matter is available for biological uptake, it may be a significant contributor to hypoxia in the Gulf of Mexico. Terrestrial sources of particulate matter are less available for biological uptake than plankton produced in the river. Isotopic analysis adds an important dimension to standard chemical and hydrologic data allowing for unique interpretations of river nutrient dynamics.

\section{Other USGS Studies of Nitrogen Processes}

Numerous studies developed to address local water-management issues are conducted under the Cooperative Water Program with various Federal, state, and local entities. These studies address a wide range of issues including (1) the effectiveness of agricultural and urban best-management practices, (2) the influence of land-use changes on the water system, (3) a comparison of river water quality to local and national water-quality standards, and (4) the effects of nutrient concentrations on aquatic biota. The results of these cooperative studies, when analyzed in combination with other monitoring, modeling, and process research results, can provide the additional information needed to make effective management decisions.

\section{Communication and Coordination of Efforts-Keys to Effective River Conservation}

A USGS goal is to deliver credible, timely, and relevant science information to inform practical and effective water-resource management and influence strategies that protect and restore water quality in the UMRB. The USGS scientists recognize that water resources and needs are so complex that a single agency cannot address all issues of interest. External coordination at all levels, integrating multidisciplinary views, is critical for a more complete understanding of the watershed and for cost-effective management, regulation, and conservation of its water resources. Partnerships are a vital element of USGS programs and studies-not only in enhancing the breadth of the science, but also in ensuring that USGS information meets the needs of local, state, regional, and national stakeholders. It is the purpose of this fact sheet and the Upper Mississippi Basin Nutrient Initiative Web page http://www.umesc.er.usgs.gov/umbni) to describe the roles, resources, and capabilities of the USGS, and to enhance communication and interaction among those currently involved in UMRB studies, both within and outside of USGS.

\section{Selected References}

Alexander, R.A., Smith, R.B., and Schwarz, G.E., 2000, Effect of stream channel size on the delivery of nitrogen to the Gulf of Mexico: Nature, v. 403, p. $758-761$.

Battaglin, W.A., Kendall, C., Chang, C.C.Y., Silva, S.R., and Campbell, D.H., 2001, Isotopic and chemical composition of inorganic and organic water-quality samples from the Mississippi River Basin 1997-98: U.S.Geological Survey: WaterResources Investigations Report 01-4095, 57 p.

Broshears, R.E., Clark, G.M., and Jobson, H., 2001, Simulation of stream discharge and transport of nitrate and selected herbicides in the Mississippi River Basin: Hydrological Processes, v. 15, p.11571167.

Carlson, B.C., 1999, Multi-use management on the Upper Mississippi River: public preferences for future actions: Master of Science Thesis, University of Minnesota, $84 \mathrm{p}$.

Chang, C.C.Y., Kendall, C., Silva, S.R., Battaglin, W.A., and Campbell, D.H., 2002, Nitrate stable isotopes: tools for determining nitrate sources among different land uses in the Mississippi River Basin: Canadian Journal of Fisheries and Aquatic Sciences, v. 59 , p. $1874-1885$.

Goolsby, D.A., Battaglin, W.A., Lawrence, G.B., Artz, R.S., Aulenbach , B.T., Hooper, R.P., Keeney, D.R., and Stensland, G.J., 1999, Flux and sources of nutrients in the Mississippi-Atchafalaya River Basin-Topic 3 report for the integrated assessment on hypoxia in the Gulf of Mexico: Silver Spring, Maryland, NOAA Coastal Ocean Office, NOAA Coastal Ocean Program Decision Analysis Series No. 17,130 p.

Goolsby, D.A., and Battaglin, W.A., 2000, Nitrogen in the Mississippi Basin-Estimating sources and predicting flux to the Gulf of Mexico: U.S. Geological Survey Fact Sheet 135-00.

Goolsby, D.A., and Battaglin, W.A., 2001, Long-term changes in concentrations and flux of nitrogen in the Mississippi River Basin: Hydrological Processes, v. 15 , p. 1209-1226.

Groschen, G.E., Harris, M.A., King, R.B., Terrio, P.J., and Warner, K.L., 2001, Water quality in the Lower Illinois River Basin, Illinois, 1995-98: U.S. Geological Survey Circular 1209, 36 p.

Helsel, D.R., and Hirsch, R.M., 1991, Statistical methods in water resources: U.S. Geological Survey Techniques of Water-Resources Investigations, book 4, chap. A3, 510 p.

Hirsch, R.M., and Norris, J.M., 2001, National Streamflow Information Program-implementation plan and progress report: U.S. Geological Survey Fact Sheet FS-048-01.

Kalkoff, S.J., Barnes, K.K., Becher, K.D., Savaco, M.E., Schnoebelen, D.J., Sadorf, E.M., Porter, S.D., and Sullivan, D.J., 2001, Water quality in the Eastern Iowa Basins, Iowa and Minnesota, 1996-98: U.S. Geological Survey Circular 1210, 37 p.

Kendall, C., Silva, S.R., and Kelly, V.J., 2001, Carbon and nitrogen isotopic compositions of particulate organic matter in four large-river systems across the United States: Hydrological Processes, v. 15 , p. 1301-1346

Rabalais, N.N., Turner, R.E., Dubravko, J., Dortsch, Q., and Wisman, W.J., Jr., 1999, Characterization of hypoxia-topic 1 report for the integrated assessment on hypoxia in the Gulf of Mexico: NOAA Coastal Ocean Program Decision Analysis Series No. 17, $167 \mathrm{p}$. 


\section{Further Research-Filling in the Knowledge Gaps}

The overall objective of scientific studies and data-collection programs is to provide information that can be used to better understand how an ecosystem functions, identify problems that might interfere with its normal function, and contribute to the development of effective management policies and actions to address such problems. A large body of knowledge about nutrients in the Upper Mississippi River Basin (UMRB) has been developed through studies over the past 25 years. More specific information about watershed processes is needed, however, for better understanding of nutrient fate and transport in large river systems in general and the UMRB in particular. Some of the unanswered science questions are

- What are the most important controls for the movement and transport of nutrients from land to tributaries and backwaters and then downstream to the main stem?

- What level of accuracy is needed in information on mapped geographic features such as drainage boundaries and associated stream reaches to produce reliable models of nutrient transport?

- How do nutrient chemistry, mobility, and toxicity change with changes between aerobic and anaerobic conditions? Are these changes of sufficient magnitude to produce significant effects (such as toxicity and algal blooms) on ecosystems?

- How have best-management practices in the UMRB affected nutrient movement off the land?

- How does groundwater inflow affect nutrient chemistry, mobility, and toxicity in the basin and the waters of the Upper Mississippi River?

- Some substantial stream-flow changes have been observed in tributaries of the UMRB. Are these changes important in affecting sediment and nutrient loading? What are the connections, if any, between these trends and global climate change?

- What is the effect of nutrient loading on the biodiversity and productivity of the UMRB ecosystem? Under what conditions are phosphorus or suspended sediment, rather than nitrogen, the primary factors of concern with respect to this problem?
Richardson, W.B., Strauss, E.A., Monroe, E.M., Bartsch, L.A., Cavanaugh, J.C., Rabuck, L.D., and Soballe, D.M., in press, Denitrification in the Upper Mississippi River: rates, controls, and contribution to nitrate flux: Canadian Journal of Fisheries and Aquatic Sciences.

Stark, J.R., Hanson, P.E., Goldstein, R.M., Fallon, J.D., Fong, A.L., Lee, K.E., Kroening, S.E., and Andrews, W.J., 2001, Water quality in the Upper Mississippi River Basin, Minnesota, Wisconsin, South Dakota, Iowa, and North Dakota, 1995-98: U.S. Geological Survey Circular 1211, 35 p.

Strauss, E.A., Cavanaugh, J.C., Richardson, W.B., Bartsch, L.A., Bruesewitz, D.A., and Soballe, D.M., 2003, Nitrogen cycle responses to water level manipulations in the Upper Mississippi River: 51st Annual Meeting of the North American Benthological Society, Athens, Georgia, p. 246-247.

Strauss, E.A., Richardson, W.B., Bartsch, L.A., Cavanaugh, J.C., Bruesewitz, D.A., Imker, H.J., Heinz, J.A., and Soballe, D.M., in press, Nitrification in the Upper Mississippi River: patterns, controls and contribution to the nitrate budget: Journal of the North American Benthological Society.

Sullivan, D.J., 1999, Nutrients and suspended solids in surface waters of the Upper Illinois River Basin in Illinois, Indiana, and Wisconsin, 1978-97: U.S. Geological Survey Water-Resources Investigations Report 99-4275, 57 p.

U.S. Environmental Protection Agency, 2003, Total Maximum Daily Loads: National Section 303(d) List Fact Sheet, accessed July 31, 2003, at http: //oaspub.epa.gov/waters/national_rept.control.

U.S. Geological Survey, 1999a, Ecological status and trends of the Upper Mississippi River System, 1998-A report of the Long Term Resource Monitoring Program: U.S. Geological Survey, Upper Midwest Environmental Sciences Center, La Crosse, Wisconsin, LTRMP 99-T001, 236 p.

U.S. Geological Survey, 1999b, Streamflow information for the next century-A plan for the National Streamflow Information Program of the U.S. Geological Survey: U.S. Geological Survey Open-File Report 99-456, 13 p.

\section{Contact Information}

For information on the various studies and ongoing USGS programs discussed in this document, you may refer to the published literature cited or contact these program offices
National Programs, including NASQAN, NAWQA, and Toxic Substances Hydrology

U.S. Geological Survey

Office of Water Quality

412 National Center

Reston, Virginia 20192

Telephone: (703) 648-6862

Website: http://water.usgs.gov/owa

Cooperative Water Program

U.S. Geological Survey

409 National Center

Reston, Virginia 20192

Telephone: (703) 648-6843

Website: http://water.usgs.gov/coop

Upper Midwest Environmental Sciences Center

U.S. Geological Survey

2630 Fanta Reed Road

La Crosse, Wisconsin 54603

Telephone: (608) 783-6451

Website: http://www.umesc.er.usgs.gov

Illinois

District Chief

U.S. Geological Survey

221 North Broadway Avenue

Urbana, Illinois 61801

Telephone: (217) 344-0037, ext. 3003

Website: http://il.water.usgs.gov

Iowa

District Chief

U.S. Geological Survey

P.O. Box 1230

Iowa City, Iowa 52244

Telephone: (319) 358-3600

Website: http://ia.water.usgs.gov

Minnesota

District Chief

U.S. Geological Survey

2280 Woodale Drive

Mounds View, Minnesota 55112

Telephone: (763) 783-3100

Website: http://mn.water.usgs.gov

Missouri

District Chief

U.S. Geological Survey

1400 Independence Road

Rolla, Missouri 65401

Telephone: (573) 308-3664

Website: http://mo.water.usgs.gov

Wisconsin

District Chief

U.S. Geological Survey

8505 Research Way

Middleton, Wisconsin 53562-3581

Telephone: (608) 821-3801

Website: http://wi.water.usgs.gov 